\title{
ANALISIS YURISDIS PERLINDUNGAN HUKUM NASABAH BANK TERHADAP KERAHASIAAN BANK DI INDONESIA
}

\author{
Oleh : \\ Zulfi Diane Zaini \\ Universitas Bandar Lampung
}

\begin{abstract}
Abstrak
Dalam rangka menghindari terjadinya penyalahgunaan keuangan nasabah maka dibuat aturan khusus yang melarang bank untuk memberikan informasi tercatat kepada siapapun berkaitan dengan keuangan nasabah, simpanan dan peyimpannya, kecuali dalam hal-hal tertentu yang disebutkan secara tegas di dalam Undang-Undang Perbankan. Berdasarkan hal tersebut maka permasalahan yang akan diteliti dalam penelitian ini adalah bagaimana upaya bank di dalam menjaga keamanan rahasia bank.

Berdasarkan hasil penelitian diketahui bahwa kepercayaan masyarakat atas lembaga perbankan tumbuh dan berkembang dikarenakan pada lembaga tersebut adanya suatu unsur berupa kerahasiaan bank. Rahasia bank adalah segala sesuatu yang berhubungan dengan keuangan dan hal-hal lain dari nasabah bank yang menurut kelaziman dunia perbankan tidak boleh secara terbuka diungkapkan kepada pihak masyarakat. UndangUndang Perbankan Nomor 10 Tahun 1998 telah mewajibkan penerapan rahasia bank demi tetap menjaga kepercayaan masyarakat terhadap lembaga perbankan. Akan tetapi dalam praktiknya masih sulit dijalankan karena belum ada keseragaman dalam penentuan kategori yang termasuk rahasia bank.
\end{abstract}

Kata kunci: perlindungan hukum nasabah bank, lembaga perbankan, rahasia bank

\begin{abstract}
In order to avoid financial abuse, the customer made a special rule that prohibits banks to provide recorded information to anyone related to finance customers, deposits and its depositors except in certain cases mentioned explicitly in in the Banking Act. Based on such matters, the issues to be studied in this research is how the bank's efforts in maintaining the security of bank secrecy. Based on the research results revealed that public confidence on banking institutions to grow and thrive because in the presence of an element of the institution in the form of bank secrecy. Bank secrecy is everything related to finances and other things from the customer's bank in the ordinary course of banking should not be publicly disclosed to the public. The Banking Act Number 10 of Year 1998 has required the application of bank secrecy for the sake of maintaining public confidence in the banking institutions. But in practice it is still difficult to implement because there is no uniformity in the determination of categories including bank secrecy.
\end{abstract}

Keywords: bank customer protection law, banking institutions, bank secrecy 


\section{Pendahuluan}

Perbankan merupakan lembaga keuangan dari setiap Negara, oleh karenanya perbankan merupakan salah satu motor penggerak pembangunan seluruh bangsa. Tidak dapat disangkal bahwa di dalam mencapai tujuan pembangunan nasional, yaitu mewujudkan masyarakat yang adil dan makmur berdasarakan Pancasila dan Undang-Undang Dasar 1945, perbankan mempunyai peran yang sangat penting.

Sebagai salah satu motor penggerak pembangunan bangsa, lembaga perbankan mempunyai peran yang sangat strategis karena bank mempunyai fungsi untuk menghimpun dana dari masyarakat sebagai nasabah dalam bentuk simpanan dan menyalurkan kembali dana tersebut kepada masyarakat yang membutuhkannya. Bank diharapkan dapat meyerasikan, meyelaraskan, dan pemerataan, pembangunan berikut hasil-hasilnya, pertumbuhan ekonomi dan stabilitas nasional yang pada akhirnya mengarah pada peningkatan taraf hidup masyarakat banyak.

Lembaga Perbankan dituntut untuk dapat bekerja secara profesional, dapat membaca dan menelaah, serta menganalisis semua kegiatan dunia usaha serta perekonomian nasional. Oleh karena itu maka lembaga perbankan perlu dibina dan diawasi secara terus menerus agar dapat berfungsi dengan efisien, sehat, wajar, mampu bersaing, dan dapat melindungi dana yang disimpankan oleh nasabah dengan baik serta mampu menyalurkan dana simpanan tersebut kepada sektor produksi yang benar-benar produktif sesuai dengan sasaran pembangunan, sehingga dana yang disalurkan dalam bentuk pinjaman tersebut tidak sia-sia.

Sebaliknya nasabah yang mempercayakan dana simpanannya untuk dikelola oleh pihak bank juga harus mendapat perlindungan dari tindakan yang dapat merugikan nasabah yang mungkin dilakukan pengelola bank. Selain itu untuk menjaga nama baik nasabah, harus diatur kapan dan dalam hal yang bagaimana bank diperkenankan untuk memberikan informasi kepada pihak ketiga mengenai segala sesuatu yang berhubungan dengan keuangan dan hal-hal lain dari nasabah yang diketahui oleh bank. Nasabah hanya akan mempergunakan jasa bank untuk menyimpan dananya apabila ada jaminan dari bank bahwa pihak bank tidak akan menyalahgunakan pengetahuannya tentang simpanan dan keadaan keuangan nasabahnya. Untuk menghindari terjadinya penyalahgunaan keuangan nasabah maka dibuatlah aturan khusus yang melarang bank untuk memberikan informasi tercatat kepada siapapun berkaitan dengan keadaan 
keuangan nasabah, simpanan dan peyimpanannya sebagai mana diatur dalam UndangUndang Nomor 10 Tahun 1998 tentang Perbankan kecuali dalam hal-hal tertentu yang disebutkan secara tegas di dalam undan-undang tersebut. Hal inilah yang disebut "rahasia bank".

Kelancaran dan keamanan kegiatan perbankan harus mendapat perhatian yang sungguh-sungguh dari semua aparat penegak hukum, karena apabila terjadi tindak pidana dalam bidang perbankan akan menyebabkan kerugian yang sangat besar bagi Negara. Oleh sebab itu segala usaha preventif maupun reprensif harus digalakkan untuk menanggulangi kejahatan perbankan tersebut.

Pelanggaran terhadap rahasia bank merupakan salah satu bentuk kejahatan, selanjutnya yang menjadi masalah bukan hanya karena adanya pembocoran rahasia, akan tetapi kenyataan bahwa rahasia bank kadang kala dijadikan sebagai tempat berlindung bagi penyelewengan administrasi dan kolusi pada lembaga perbankan.

Berdasarkan hal tersebut maka penulis merasa perlu pengkajian untuk melihat sejauh apa upaya hukum yang dilakukan oleh pihak bank untuk memberikan rasa aman kepada nasabah dalam menitipkan dananya pada lembaga perbankan, sehingga penelitian ini diberi judul "Analisis Yuridis Perlindungan Hukum Nasabah Bank terhadap Kerahasiaan Bank di Indonesia”. Permasalahan yang dibahas adalah bagaimana upaya bank dalam menjaga keamanan rahasia bank?

Untuk menjawab dan menjelaskan permasalahan tersebut, artikel hasil penelitian ini menggunakan pendekatan yuridis normatif, yaitu pendekatan dengan melihat masalah hukum sebagai kaidah yang dianggap sesuai dengan penelitian yuridis normatif. Selanjutnya penelitian yuridis normatif ini dilakukan terhadap hal-hal yang bersifat teoritis yaitu suatu pendekatan yang dilakukan melalui studi kepustakaan (library research) dengan mempelajari asas-asas hukum yang ada dalam teori/pendapat sarjana dan peraturan perundang-undangan yang berlaku. Data yang digunakan adalah data sekunder, yakni data yang diperoleh dari studi kepustakaan (library research); data ini diperoleh dari dengan cara mempelajari, membaca, mengutip literatur-literatur atau peraturan perundang-undangan yang berkaitan dengan pokok permasalahan penelitian ini.

\section{Pembahasan}




\section{Lembaga Keungan, Bank, dan Rahasia Bank}

Lembaga keuangan dalam arti luas adalah sebagai perantara dari pihak yang mempunyai kelebihan dana (surplus of founds) dengan pihak yang kekurangan dana (lack of funds), sehingga peranan dari lembaga keuangan yang sebenarnya yaitu sebagai perantara keuangan masyarakat (financial intermediary). Dalam arti yang luas ini termasuk di dalamnya lembaga perbankan, perasuransian, dana pension, penggadaian dan sebagainya yang menjembatani antara pihak yang berkelebihan dana dengan pihak yang memerlukan dana. ${ }^{1}$

Dari pengertian yang luas maka lembaga-lembaga yang termasuk atau menjadi bagian dari lembaga keuangan tersebut dengan sendirinya mempunyai perbedaan, fungsi dan kelembagaannya juga mempunyai derivasi-derivasi menurut fungsi dan tujuannya. Adapun aspek kesamaannya dari lembaga keuangan tersebut yaitu semua lembaga keuangan merupakan lembaga yang kegiatannya didasarkan kepada kepercayaan masyarakat, dijalankannya harus dengan penuh kehati-hatian, memilik resiko yang tinggi sehingga tidak berlebihan mendapatkan pengawasan dan pembinaan yang khusus, juga sangat diatur secara ketat. ${ }^{2}$

Dari semua lembaga-lembaga yang termasuk di dalam lembaga keuangan tersebut, dapat kita klasifikasikan kepada dua jenis lembaga yaitu lembaga keuangan Bank, dan lembaga keuangan bukan Bank. Menurut Dahlan Siamat lembaga keuangan adalah badan usaha yang kekayaannya terutama dalam bentuk aset keuangan atau tagihan (claims) dibandingkan dengan aset nonfinansial atau aset real. Lembaga keuangan memberikan pembiayaan atau kredit kepada nasabah dan menanamkan dananya dalam surat-surat berharga. Di samping itu, lembaga keuangan juga menawarkan berbagai jasa keuangan antara lain menawarkan berbagai jenis skema tabungan, proteksi asuransi, program pensiun, penyediaan sistem penawaran dan mekanisme transfer dana. ${ }^{3}$ Kemudian Kasmir mendefinisikan lembaga keuangan adalah setiap perusahaan yang bergerak di bidang keuangan, menghimpun dana,menyalurkan dana atau kedua-duanya, artinya kegiatan yang dilakukan oleh lembaga keuangan selalu

\footnotetext{
${ }_{1}^{1}$ Muhammad Djumhana, Hukum Perbankan Di Indonesia, PT. Citra Aditya Bakti, Bandung, 2003, hal. 7.

${ }^{2}$ Ibid, hal. $82-83$

${ }^{3}$ Andri Soemitra, Bank dan Lembaga Keuangan Syariah, Prenada Media, Jakarta, 2010, hal. 29.
} 
berkaitan dengan bidang keuangan, apakah kegiataannya hanya menghimpun dana atau hanya menyalurkan dana atau kedua-duanya menghimpun dan menyalurkan dana. ${ }^{4}$

Berdasarkan pengertian lembaga keuangan di atas, maka dapat disimpulkan bahwa lembaga keuangan adalah setiap perusahaan yang bergerak di bidang keuangan, menghimpun dana, menyalurkan dana atau kedua-duanya, dan merupakan badan usaha yang kekayaannya terutama dalam bentuk aset keuangan atau tagihan (claims) dibandingkan dengan aset nonfinansial atau aset real.

Bank sebagai salah satu lembaga keuangan yang paling penting dan besar peranannya dalam kehidupan masyarakat. Dalam menjalankan peranannya maka bank bertindak sebagai salah satu bentuk lembaga keuangan yang bertujuan memberikan kredit, dan jasa-jasa keuangan lainnya. Adapun pemberian kredit itu dilakukan baik dengan modal sendiri atau dengan dana-dana yang dipercayakan oleh pihak ketiga maupun dengan jalan memperedarkan alat-alat pembayaran baru berupa uang giral. ${ }^{5}$

Dari pengertian tersebut di atas, bank menjalankan perniagaan dana (uang). Jadi tegasnya bank sangat erat kaitannya dengan kegiatan peredaran uang, dalam rangka melancarkan seluruh aktivitas keuangan masyarakat. Dengan demikian bank berfungsi sebagai pedagang dana (money lender) yaitu wahana yang dapat menghimpun dan menyalurkan dana masyarakat secara efektif dan efisien dan lembaga yang melancarkan transaksi perdagangan dan pembayaran uang. ${ }^{6}$

Melihat praktik operasional perbankan yang ada, dapat dibedakan jenis-jenis bank. Jenis bank secara teoritis ditentukan dari segi fungsinya, kepemilikannya, dan penciptaan uang giral. ${ }^{7}$ Dari segi fungsinya serta tujuan usahanya, kita mengenal ada empat jenis bentuk bank, yaitu pertama, Bank Sentral (central bank), adalah bank yang dapat bertindak sebagai bankers bank pimpinan, penguasa moneter, mendorong dan mengarahkan semua jenis bank yang ada. Kedua, Bank Umum (commercial bank) yaitu bank baik milik negara, swasta, maupun koperasi, yang dalam pengumpulan dananya terutama menerima simpanan dalam bentuk giro, deposito, serta tabungan dan dalam usahanya terutama memberikan kredit jangka pendek. Dikatakan sebagai bank umum karena bank tersebut mendapatkan keuntungannya dari selisih bunga yang diterima dari

\footnotetext{
${ }^{4}$ Ibid.

${ }^{5}$ Ibid, hal. 82 .

${ }^{6}$ Ibid.

${ }^{7}$ Munir Fuadi, Hukum Perbankan Modern, PT. Citra Aditya Bakti, Bandung, 1999, hal. 77.
} 
peminjam dengan yang dibayarkan oleh bank kepada depositor (disebut pread). Ketiga, Bank Tabungan (saving bank) yaitu bank baik milik negara swasta, maupun koperasi yang dalam pengumpulan dananya terutama menerima simpanan dalam bentuk tabungan sedangkan usahanya terutama memperbungakan dananya dalam kertas berharga. Keempat, Bank Pembangunan (development bank) yaitu bank baik milik negara, swasta, maupun koperasi, baik pusat maupun daerah yang dalam pengumpulan dananya terutama menerima simpanan dalam deposito dan atau mengeluarkan kertas berharga jangka menengah dan panjang, sedangkan usahanya terutama memberikan kredit jangka menengah dan panjang di bidang pembangunan. ${ }^{8}$

Dari segi kepemilikannya,kita mengenal ada empat jenis, yaitu Bank Milik Negara, Bank Milik Pemerintah Daerah, Bank Milik Swasta Baik Dalam Negeri Maupun Asing, dan Bank Koperasi. ${ }^{9}$

Selanjutnya dari segi penciptaan uang giral, dikenal ada dua jenis yaitu bank primer dan bank sekunder. Bank Primer adalah bank yang dapat menciptakan uang melalui simpanan masyarakat yang ada padanya yaitu simpanan likuid dalam bentuk giro yang dapat bertindak sebagai bank primer ini adalah bank umum. Bank Sekunder adalah bank-bank yang tidak bisa menciptakan uang melalui masyarakat yang ada padanya, bank ini hanya bertugas sebagai perantara dalam menyalurkan kredit. Umumnya yang bergerak pada bank sekunder, adalah bank tabungan, bank pembangunan, bank hipotik, yang sekarang ada di Indonesia adalah berupa bank perkreditan rakyat, semuanya bank tersebut tidak boleh menciptakan uang giral. ${ }^{10}$

Dalam dunia perbankan terdapat ketentuan tentang rahasia bank yang bertujuan dalam rangka perlindungan terhadap nasabah. Rahasia bank adalah segala sesuatu yang berhubungan dengan keuangan, dan hal-hal lain dari nasabah bank yang menurut kelaziman dunia perbankan tidak boleh secara terbuka diungkapkan kepada pihak masyarakat. Dalam hubungan ini yang menurut kelaziman wajib dirahasiakan oleh bank, adalah seluruh data dan informasi mengenai segala sesuatu yang berhubungan dengan keuangan, dan hal-hal lain dari orang, dan badan yang diketahui oleh bank karena kegiatan usahanya. ${ }^{11}$

\footnotetext{
${ }^{8}$ Ibid, hal. 80-81.

${ }^{9}$ Ibid, hal. 78 .

${ }^{10}$ Ibid, hal. 83.

${ }^{11}$ Muhammad Djumhana, Rahasia Bank (Ketentuan Dan Penerapannya di Indonesia), PT.Citra Aditya Bakti, Bandung, 1996, hal. 111.
} 
Kerahasian informasi yang terlahir dalam kegiatan perbankan ini diperlukan baik untuk kepentingan bank maupun untuk kepentingan nasabah itu sendiri. Nasabah hanya akan mempercayakan uangnya pada lembaga perbankan ataupun memanfaatkan jasa perbankan lainnya apabila dari lembaga tersebut ada jaminan bahwa pengetahuan tentang simpanan dan keadaan keuangan nasabah tidak akan disalahgunakan oleh mereka yang bergerak di dalam kegiatan perbankan tersebut, atau oleh pihak lain yang tidak berhak dan berkepentingan. Ketentuan tersebut menegaskan bahwa lembaga perbankan harus memegang teguh keterangan yang tercatat olehnya, ketentuan itu juga berlaku pula bagi pihak terafiliasi dalam kegiatan operasional perbankan tersebut. ${ }^{12}$

Bank sebagai lembaga keuangan yang dipercaya oleh masyarakat (fiduciary financial institusion) dihadapkan pada dua kewajiban yang saling bertentangan dan seringkali tidak dapat dirundingkan. Di satu pihak bank mempunyai kewajiban untuk tetap merahasiakan keadaan dan catatan keuangan nasabahnya (duty of confidentiality). Kewajiban ini timbul dan erat kaitannya dengan kepercayaan yang diberikan masyarakat/para nasabahnya kepada bank selaku lembaga keuangan pengelola keuangan atau sumber dana masyarakat. Kewajiban menjaga rahasia ini sering timbul atas dasar kepercayaan (fiduciary duty). Di lain pihak bank juga berkewajiban untuk mengungkapkan (disclose) keadaan, dan catatan keuangan nasabahnya dalam keadaankeadaan tertentu. ${ }^{13}$

Bank sebagai lembaga keuangan yang dipercaya masyarakat yang akan menjembatani potensi, dan sumber-sumber dana yang dimiliki masyarakat dengan berbagai kegiatan ekonomi/pembangunan. Berdasarkan Pasal 40 Undang-Undang Nomor 7 Tahun 1992 tentang Perbankan Rahasia Bank dalam ayat (1), yaitu bank dilarang memberikan keterangan yang tercatat pada bank tentang keadaan keuangan dan hal-hal lain dari nasabahnya, yang wajib dirahasiakan oleh bank menurut kelaziman dalam dunia perbankan, kecuali dalam hal sebagaimana dimaksud dalam Pasal 41, Pasal 42, Pasal 43, dan Pasal 44 dan ayat (2), yaitu ketentuan sebagaimana dimaksud dalam ayat (1) Undang-Undang Nomor 7 Tahun 1992 berlaku pula bagi pihak terafiliasi.

Selanjutnya, Rahasia bank dalam Pasal 40 ayat (1) Undang-Undang Nomor 10 Tahun 1998 tentang Perbankan (Perubahan dan Penambahan beberapa pasal atas Undang-Undang Nomor 7 Tahun 1992), yaitu bank wajib merahasiakan keterangan

${ }^{12}$ Ibid, hal. 112.

${ }^{13} \mathrm{Ibid}$, hal. 112-113. 
mengenai nasabah penyimpan dan simpanannya, kecuali dalam hal sebagaimana dimaksud dalam Pasal 41, Pasal 41A, Pasal 42, Pasal 43, Pasal 44, dan Pasal 44A, dalam ayat (2) yaitu ketentuan sebagaimana dimaksud dalam ayat (1) berlaku pula bagi pihak terafiliasi.

Perbedaan mendasar mengenai pengaturan kerahasiaan bank dalam UndangUndang Nomor 7 Tahun 1992 tentang Perbankan dengan Undang-Undang Nomor 10 Tahun 1998 tentang Perbankan mengenai rahasia bank yaitu bank wajib merahasiakan keterangan mengenai nasabah penyimpan dan simpanannya. Dengan demikian saat ini berdasarkan Undang-Undang Nomor 10 Tahun 1998 yang menjadi rahasia bank adalah hanya dana simpanan nasabah.

Dalam mempelajari teori tentang rahasia bank terdapat dua pendapat tentang teori rahasia bank ini, yaitu: ${ }^{14}$

1. Teori rahasia bank bersifat mutlak, yaitu bahwa bank berkewajiban menyimpan rahasia nasabah yang diketahui oleh bank karena kegiatan usahanya dalam keadaan apapun, biasa atau dalam keadaan luar biasa.

2. Teori yang kedua adalah rahasia bank bersifat nisbi, yaitu bahwa bank diperbolehkan membuka rahasia nasabahnya, bila untuk suatu kepentingan mendesak, misalnya demi kepentingan Negara.

Penganut aliran mutlak berpendirian, bahwa semua hal yang bersangkutan dengan orang, mutlak harus dirahasiakan tanpa pengecualian. Teori ini terlalu individualistis bahkan sebenarnya bertentangan dengan kepentingan umum. Tidaklah dapat diterima adanya suatu"secret absolute", meskipun itu di lingkungan pekerjaan kepercayaan seperti kalangan kedokteran dan perbankan. ${ }^{15}$

Pendirian aliran nisbi akan bersedia melepaskan kewajibannya untuk menyimpan rahasia demi kepentingan masyarakat. Dalam praktiknya aliran ini akan berpijak pada asas proporsional dan asas subside dalam pembukaan rahasia tersebut. ${ }^{16}$ Hukum kerahasiaan berkaitan dengan perlindungan rahasia-rahasia baik menyangkut perdagangan, rahasia yang sifatnya pribadi atau mengenai pemerintahan. Rahasia bank adalah satu bagian yang dilindungi oleh hukum kerahasian.

Menyangkut rahasia bank terkait pula pihak-pihak yang berhubungan dengan bank tersebut baik secara langsung maupun tidak langsung. Pihak yang secara langsung

\footnotetext{
${ }^{14}$ Ibid, hal. 116.

${ }^{15} \mathrm{Ibid}$.

${ }^{16}$ Ibid, hal. 116-117.
} 
yaitu mereka yang bekerja atau mempunyai hubungan erat dengan bank seperti anggota komisaris. Adapun pihak yang tidak secara langsung yaitu mereka mempunyai keterkaitan dengan kegiatan bank, seperti konsultan hukumnya, akuntan publiknya, dan pihak jasa penilai. Mereka semua terikat pada rahasia jabatannya. Rahasia jabatan adalah menyangkut informasi yang diterima seseorang dari pihak lain dalam rangka hubungan profesinya. ${ }^{17}$

Di atas telah dijelaskan bahwa guna melindungi informasi dikenal adanya hukum kerahasiaan. Hukum kerahasian adalah hukum yang berisikan kaidah-kaidah yang berkaitan dengan perlindungan rahasia baik yang menyangkut rahasia perdagangan, rahasia yang sifatnya pribadi atau mengenai rahasia pemerintahan.

Objek dari hukum kerahasian ini meliputi informasi yang terjadi karena tugas dan fungsi jabatan seseorang, dan atau karena suatu kegiatan. Dengan demikian kita dapat membagi informasi yang dirahasiakan itu ke dalam dua macam. Informasi yang harus dirahasiakan karena tugas dan jabatan misalnya informasi dalam hubungan pasien dengan dokter atau klien dengan pengacaranya. Sedangkan informasi yang harus dirahasiakan karena kegiatannya, misalnya informasi bisnis mengenai data tentang desain atau seorang wartawan yang harus merahasiakan sumber beritanya. ${ }^{18}$

Kewajiban untuk menyimpan rahasia suatu informasi bersumber kepada kewajiban moral serat tuntutan kepentingan masyarakat untuk terbentuknya suatu hubungan berdasarkan saling percaya. Semua itu merupakan asas terpenting dan berhubungan secara intrinsik dengan tugas dan fungsi suatu jabatan/pekerjaan. ${ }^{19}$

Informasi mengenai kegiatan bank terutama hubungannya antara nasabah dengan bank merupakan bagian dari rahasia bank dan itu adalah salah satu bagian yang dilindungi oleh hukum kerahasian. Dasar alasan yang melandasi hukum kerahasian ini adalah bahwa hukum tersebut dapat mencegah seseorang untuk membuka/membocorkan informasi yang diberikan kepadanya atau menyalahgunakan informasi yang diketahuinya tersebut. Dengan demikian bila terjadi pembocoran/pembukaan informasi secara melawan hukum atau menyalahgunakan

\footnotetext{
${ }^{17}$ Ibid, hal. 121.

${ }^{18}$ Ibid, hal. 130.

${ }^{19}$ Ibid.
} 
informasi tersebut, maka ketentuan hukum dapat dikenakan kepada si pelaku pembocoran atau penyalahgunaan informasi tersebut. ${ }^{20}$

\section{Perlindungan Hukum Nasabah Bank terhadap Kerahasiaan Bank}

Menurut Pasal 1 angka 28 Undang-Undang Perbankan, yang dimaksud dengan rahasia bank adalah segala sesuatu yang berhubungan dengan keterangan mengenai nasabah penyimpan dan simpanannya. Jadi, Undang-Undang Perbankan mempertegas dan mempersempit pengertian rahasia bank dibandingkan dengan ketentuannya dalam pasalpasal dari Undang-Undang sebelumnya, yaitu Undang-Undang Nomor 7 Tahun 1992 tentang Perbankan, yang tidak khusus menunjukan bank kepada nasabah deposan saja. ${ }^{21}$ Dari pengertian yang diberikan oleh Pasal 1 angka 28 dan Pasal-pasal lainnya, dapat ditarik unsur-unsur dari rahasia bank itu sendiri, yaitu sebagai berikut :

1. Rahasia bank tersebut berhubungan dengan keterangan mengenai nasabah penyimpan dan simpanannya.

2. Wajib dirahasiakan oleh bank, kecuali termasuk ke dalam kategori perkecualian berdasarkan prosedur dan peraturan perundang-undangan yang berlaku.

3. Pihak yang dilarang membuka rahasia bank adalah pihak bank sendiri dan atau pihak terafiliasi. Yang dimaksud dengan pihak terafiliasi adalah sebagai berikut :

a. Anggota dewan komisaris, pengawas, direksi, atau kuasanya, pejabat atau karyawan bank yang bersangkutan.

b. Anggota pengurus, pengawas, pengelola, atau kuasanya, pejabat atau karyawan bank, khusus bagi bank berbentuk badan hukum koperasi sesuai dengan peraturan perundangan-undangan yang berlaku.

c. Pihak pemberi jasa kepada bank yang bersangkutan, termasuk tetapi tidak terbatas pada akuntan public, penilai konsultasi hukum, dan konsultan lainnya

d. Pihak yang menurut penilaian bank Indonesia turut serta memengaruhi pengolalaan bank, tetapi tidak terbatas pada pemegang, keluarga direksi, dan keluarga pengurus.

Rahasia bank merupakan hal yang penting karena bank sebagai lembaga kepercayaan wajib merahasiakan segala sesuatu yang berhubungan dengan nasabah

${ }^{20}$ Ibid, hal. 131.

${ }^{21}$ Adrian Sutedi, Op.cit, hal. 5. 
penyimpan dan simpanannya. Oleh karena itu, baik bank sebagai entity dan pihak terafiliasi, termasuk pegawai dan manajemen bank yang bersangkutan wajib mengetahui mengenai peraturan rahasia bank ini, untuk menghindari sanksi pidana atau administratif serta sanksi sosial dari masyarakat.

Penafsiran resmi mengenai rahasia bank, memberikan gambaran sebagai berikut bahwa hal-hal yang dirahasiakan tersebut meliputi: ${ }^{22}$

1. Keadaan keuangan nasabah yang tercatat padanya, ialah keadaan mengenai keuangan yang terdapat pada bank yang meliputi segala simpanannya yang tercantum dalam semua pos pasiva, dan segala pos aktiva yang merupakan pemberian kredit dalam berbagai macam bentuk kepada yang bersangkutan.

2. Hal-hal lain yang harus dirahasiakan oleh bank menurut kelaziman dalam dunia perbankan, ialah segala keterangan orang, dan badan yang diketahui oleh bank karena kegiatan usahanya, yaitu :

a. pemberian pelayanan dan jasa dalam lalu-lintas uang, baik dalam maupun luar negeri;

b. pendiskontoan, dan jual beli surat berharga;

c. pemberian kredit.

Melakukan penerapan dalam hal-hal (informasi) yang bersifat rahasia terutama pada bank sangatlah sulit karena belum ada keseragamaan yang menentukan hal-hal (informasi) apa saja yang dapat dikategorikan sebagai suatu yang dirahasiakan oleh bank dari informasi dan data-data seorang nasabah.

Kewajiban bank untuk merahasiakan mengenai penyimpan dan simpanannya dapat bersifat eksplisit dan implisit. Pada umumnya perjanjian bank dan nasabah tidak mencantumkan secara eksplisit. Kewajiban merahasiakan tersebut misalnya terlihat pada perjanjian pembukaan rekening koran tabungan dan deposito antara bank dan nasabah. Dengan demikan, walaupun dalam perjanjian tidak diatur secara eksplisit tetapi berdasarkan azas itikad baik di dalam melaksanakan perjanjian, maka perjanjian antara bank dan nasabahnya dianggap mencantumkan secara diam-diam kewajiban merahasiakan tentang penyimpan dan simpanannya.

Hal tersebut sejalan dengan dengan Pasal 7 huruf (a) Undang-Undang Nomor 8 Tahun 1999 tentang Perlindungan Konsumen yang menyebutkan bahwa salah satu kewajiban pelaku usaha adalah beritikad baik dalam melakukan kegiatan usahanya. Dengan demikan, walaupun dalam perjanjian antara nasabah dan bank tidak diatur secara eksplisit tetapi berdasarkan azas itikad baik di dalam melaksanakan perjanjian,

${ }^{22}$ Muhammad Djumhana, Op.cit, hal. 164. 
maka perjanjian antara bank dan nasabahnya dianggap mencantumkan secara diamdiam kewajiban merahasiakan tentang penyimpan dan simpanannya. Dalam kaitannya dengan masalah rahasia bank, walaupun rahasia bank tersebut sudah diatur dalam perjanjian antara bank dan nasabah ataupun masalah rahasia bank sudah diatur dalam Undang-Undang, namun kepentingan umum tetap harus didahulukan sesuai dengan ketentuan Undang-Undang yang berlaku.

Selanjutnya, dalam hal nasabah debitur ada kemungkinan bank digugat melakukan perbuatan melanggar hukum oleh nasabah debitur bilamana dengan pengungkapan keterangan mengenai nasabah debitur dipandang oleh nasabah debitur merugikan dirinya. Gugatan ini dimungkinkan berdasarkan Pasal 1365 KUHPerdata yang secara tegas mengatur, bahwa setiap perbuatan yang melanggar hukum yang membawa kerugian kepada orang lain, mewajibkan orang yang karena salahnya menerbitkan kerugian itu, mengganti kerugian tersebut.

Bank juga dimungkinkan diancam pidana dengan menggunakan delik lain, yakni pengungkapan keterangan mengenai nasabah debitur dapat dipersangkakan sebagai kejahatan rahasia jabatan sebagaimana disebutkan dalam Pasal 322 Kitab UndangUndang Hukum Pidana (KUHP) yang berbunyi :

(1) Barang siapa dengan sengaja membuka sesuatu rahasia, yang menurut jabatannya atau pekerjaannya, baik yang sekarang maupun yang dahulu, ia diwajibkan menyimpannya, dihukum penjara selama-lamanya sembilan bulan atau denda sebanyak-banyaknya Rp. 9.000,-

(2) Jika kejahatan ini dilakukan terhadap seorang yang ditentukan, maka perbuatan itu hanya dituntut atas pengaduan orang itu.

Rahasia bank semata-mata diletakan pada kepentingan umum. Prinsip kerahasiaan bank yang bertujuan untuk melindungi kepentingan individu seorang nasabah dikorbankan demi menyeimbangkannya dengan kepentingan umum dalam hal penyelesaian perkara pidana. Di Indonesia, pengecualian rahasia bank dengan alasan kepentingan umum masih perlu disempurnakan, karena masih banyak kepentingan umum lain yang dapat dijadikan alasan untuk membuka rahasia bank yang belum tercantum pada Undang-Undang Perbankan, misalnya kepentingan Dewan Perwakilan Rakyat, Peradilan Tata Usaha Negara, Peradilan Agama, Peradilan Militer, Otoritas Asing, Badan Artbitrase dan Pemegang Saham. 
Di Indonesia, pengaturan rahasia bank lebih dititkberatkan pada alasan untuk kepentingan bank, seperti terlihat dalam penjelasan Pasal 40 Undang-Undang Nomor 7 Tahun 1992 tentang Pokok-Pokok Perbankan sebagaimana telah diubah dengan Undang-Undang Nomor 10 Tahun 1998 tentang Perbankan, yang menyebutkan bahwa kerahasiaan ini diperlukan untuk kepentingan bank itu sendiri yang memerlukan kepercayaan masyarakat yang menyimpan uangnya di bank. Pertimbangan yang demikian dikarenakan Indonesia mempunyai nilai-nilai budaya yang mengutamakan kolektifitas atau kebersamaan. Dalam hal ini, kepentingan bank dianggap sama dengan kepentingan umum karena begitu pentingnya peranan bank di dalam perekonomian suatu negara, yang dalam hal ini perbankan berfungsi sebagai perantara keuangan (financial intermediary), sarana untuk transmisi kebijakan moneter dan pelaku utama di dalam sistem pembayaran nasional.

Mengenai Pasal 43 Undang-Undang Nomor 10 Tahun 1998 ${ }^{23}$, penerapannya sempit, karena dianggap merugikan kepentingan masyarakat luas, terutama bagi kepentingan dunia bisnis. Pasal tersebut seolah-olah mengandung diskriminasi karena hanya melindungi kegiatan perusahaan perbankan saja dan tidak melindungi kepentingan perusahaan jenis lain dalam arti luas. Kalau bank yang bersangkutan prinsip kerahasiaan banknya boleh dilanggaar dan diluar itu tidak. Hal ini jelas tidak adil, seolah-olah Undang-Undang tidak perduli terhadap kesengsaraan yang dialami masyarakat luas. Padahal banyak perusahaan dengan sengaja tidak membayar kewajiban (utang) kepada mitra bisnisnya di sektor distribusi, agen atau kontraktor walau perusahaan-perusahaan tersebut akhirnya lancar (current assets) di berbagai bank.

Oleh sebab rahasia bank hanya menyangkut nasabah penyimpan dan simpanannya saja, maka dalam kasus kredit sering sekali terjadi kredit macet. Rahasia bank terlampau berpihak melindungi debitur. Hal ini menyebabkan para debitur nakal menjadi terlindungi yang dapat mengancam kepentingan umum dan perkembangan pembangunan bangsa. Jelas tampak, bahwa kredit macet secara langsung atau tidak langsung sangat merugikan kepentingan negara dan masyarakat. Jadi bukan hanya sekedar permasalahan antara debitur nakal dengan bank saja, tetapi juga menyangkut kepentingan perekonomian dan peningkatan pemerataan kesejahteraan rakyat luas. Sehingga, tidak layak rasanya membiarkan dengan memanjakan dan melindungi para 
debitur nakal dan beritikad buruk. Oleh sebab itu, jika ada debitur yang seperti itu, masyarakat luas berhak untuk mengetahuinya secara terbuka.

Setiap bank wajib memegang teguh prinsip rahasia bank. Adapun salah satu bentuk upaya yang dapat dilakukan bank di dalam menjaga keamanan rahasia bank adalah apabila ada orang yang menanyakan identitas dari nasabah, atau aktivitasnya di bank selain dari ketiga pihak yang berwenang yaitu Kejaksaan, Kepolisian dan Pengadilan, maka bank tidak memberikan informasi apapun. Bank akan merahasiakannya. Dengan melakukan upaya menjaga keamanan rahasia bank berarti secara tidak langsung juga menjaga keamanan keuangan nasabah karena rahasia bank mencakup perlindungan terhadap nasabah dan simpanannya.

Apabila terdapat perjanjian antara bank dengan nasabah, maka rahasia bank bersifat kontraktual. Sehingga apabila bank memberikan keterangan tentang keadaan keuangan nasabahnya, bank dapat digugat oleh nasabahnya berdasarkan alasan wanprestasi (cidera janji). Sebaliknya, meskipun tidak ada perjanjian antara bank dan nasabah, namun bank tetap berkewajiban untuk mempertahankan rahasia bank berdasarkan pada peraturan perundang-undangan atau konsep hukum lainnya, seperti konsep "perbuatan melawan hukum". Artinya dalam hal bank memberikan keterangan tentang nasabahnya dengan alasan perbuatan melawan hukum. Untuk hal ini nasabah harus dapat membuktikan bahwa kerugian yang dialaminya sebagai akibat dari pembocoran rahasia bank tersebut.

Upaya lain yang dilakukan oleh bank untuk menjaga keamanan rahasia bank tersebut adalah melalui :

\section{Kelaziman Operasional}

Kelaziman operasional bank yang menyangkut pada penghimpunan dana masyarakat seperti melalui giro, tabungan, deposito, dan lain sebagainya. Adapun setelah melakukan penghimpunan dana tersebut bank perlu untuk menyebarkan dana tersebut kepada masyarakat yaitu melalui pemberian kredit. Dalam operasi tersebut bank mengadakan pencatatan serta mengumpulkan data dan informasi yang berhubungan dengan usahanya maupun yang berhubungan dengan nasabahnya, contoh : dengan nasabah peminjam. Pencatatan transaksi merupakan kewajiban bank guna memenuhi kebutuhan akan data pokok yang harus dipenuhinya. Setiap bank harus mengadakan pencatatan untuk memberikan data 
bagi pelaporan-pelaporan seperti pelaporan pada bank Indonesia sebagai bank sentral, pelaporan untuk pajak, pelaporan untuk pemegang saham, pelaporan untuk nasabah dan sebagainya. Dari pencatatan itulah sebuah data diolah menjadi suatu laporan yang informatif dan mudah dimengerti oleh mereka yang menerimanya. Data dan informasi tersebut merupakan milik bank yang secara umumnya bisa dikategorikan merupakan rahasia bank.

Sebelum transaksi yang dilakukan antara bank dengan nasabah, bank terlebih dahulu memeriksa identitas nasabah tersebut. Jika seseorang nasabah tidak bertindak untuk dirinya sendiri, maka perlu disertai dengan tegas wewenangnya untuk bertindak atas nama orang lain baik untuk badan hukum maupun pihak lainnya. Biasanya identifikasi juga dilakukan dengan melakukan pengecekan terhadap referensi-referensi yang diajukan. Transaksi yang telah dilakukan akan dikumpulkan ke dalam dokumen tertentu dan dokumen tersebut nantinya akan disimpan secara permanen oleh bank.

\section{Pencatatan Pada Bank}

Pencatatan yang memadai dalam operasi bank atau transaksi yang dilakukan bank merupakan suatu keharusan. Memadai atau tidaknya catatan itu diukur dengan kesanggupannya memenuhi berbagai permintaan terhadap informasi mengenai setiap kegiatan bank. Bila pencatatan dan administrasi perbankan kurang baik maka kelancaran kegiatan perbankan akan mendapat gangguan. Dengan demikian pencatatan dan pengarsipan semua kegiatan perbankan yang dilakukan oleh bank adalah merupakan tanggung jawab dan kewajiban yang tidak dapat dihindari. Dalam perkembangan teknologi informasi yang ada sekarang ini, maka pencatatan kegiatan perbankan saat ini serta penyimpanannya dapat pula dilakukan dengan menggunakan perangkat data elektronik (komputer). Keuntungan bagi nasabah dengan adanya teknologi ini adalah nasabah dapat terlayani dengan lebih cepat dan lebih nyaman. Sedangkan keuntungan bagi bank sendiri adalah memberikan pelayanan kepada nasabah dengan lebih baik lagi serta dapat mengamankan dokumen penting tanpa memerlukan tempat atau ruangan yang luas. 
Sebagai lembaga yang bertumpu pada kepercayaan masyarakat, sudah seharusnya bank berusaha memberikan jaminan pada masyarakat bahwa bank aman dan mampu merahasiakan keterangan atau informasi mengenai nasabah dan simpanannya. Bank harus mempunyai pedoman, kebijakan, organisasi dan prosedur kerja, khususnya mengenai rahasia bank dan rahasia jabatan. Pedoman-pedoman itulah yang nantinya dipergunakan oleh bank dalam menjalankan segala kegiatannya sehingga bank dapat tetap menjaga kepercayaan masyarakat tersebut. Selebihnya penilaian selanjutnya akan dikembalikan kepada masyarakat itu sendiri apakah bank tersebut dapat dipercaya atau tidak. Secara umum ketentuan rahasia bank dipandang seringkali menimbulkan antara kepentingan nasabah dan kepentingan bisnis bank itu sendiri. Akan tetapi walaupun demikian keadaannya, bank harus tetap memegang teguh ketentuan rahasia bank ini.

Berdasarkan penjelasan di atas, maka dapat disimpulkan bahwa Upaya bank dalam menjaga keamanan rahasia bank, yaitu kelaziman operasional bank yang menyangkut pada penghimpunan dana masyarakat seperti melalui giro, tabungan, deposito, dan lain sebagainya. Adapun setelah melakukan penghimpunan dana tersebut bank perlu untuk menyebarkan dana tersebut kepada masyarakat yaitu melalui pemberian kredit.

Upaya lainnya, yaitu pencatatan yang memadai dalam operasi bank atau transaksi yang dilakukan bank merupakan suatu keharusan. Memadai atau tidaknya catatan itu diukur dengan kesanggupannya memenuhi berbagai permintaan terhadap informasi mengenai setiap kegiatan bank. Bila pencatatan dan administrasi perbankan kurang baik maka kelancaran kegiatan perbankan akan mendapat gangguan.

Dari segi hukum perdata pelaku pelanggaran rahasia bank dapat dituntut ganti rugi atas alasan perbuatan melawan hukum (tort of law) karena telah melanggar Pasal 40 Undang-Undang tentang Perbankan. ${ }^{24}$ Atas pelanggarannya, pelaku diancam dengan tuntutan ganti rugi sesuai dengan Pasal 1365 KUHPerdata. $^{25}$ Meskipun atas $^{2}$ pelanggararan Pasal 40 Undang-Undang Perbankan pelaku telah dijatuhi hukuman pidana, namun hal tersebut tidak mengurangi hak bagi pihak korban untuk menuntut

\footnotetext{
${ }^{24}$ Pasal 40 Undang-Undang Perbankan ayat (1), bahwa Bank wajib merahasiakan keterangan mengenai Nasabah Penyimpan dan simpanannya, kecuali dalam hal sebagaimana dimaksud dalam Pasal 41, Pasal 41A, Pasal 42, Pasal 43, Pasal 44, dan Pasal 44A. Ayat (2), bahwa ketentuan sebagaimana dimaksud dalam ayat (1) berlaku pula bagi Pihak Terafiliasi.

${ }^{25}$ Pasal 1365 KUHPerdata, yaitu tiap perbuatan yang melanggar hukum dan membawa kerugian kepada orang lain, mewajibkan orang yang menimbulkan kerugian itu karena kesalahannya untuk menggantikan kerugian tersebut.
} 
ganti rugi perdata. Pembukaan rahasia bank seseorang selain melanggar UndangUndang (violation a statutory) juga melanggar hak nasabah (violation of a right) yang dapat mendatangkan kerugian kepada nasabah. Penerapannya dapat disetujui sepanjang pelanggaran dilakukan terhadap kepentingan nasabah atau debitur yang beritikad baik.

\section{Kesimpulan}

Berdasarkan penjelasan hasil penelitian, maka dapat disimpulkan, yaitu upaya bank dalam menjaga keamanan rahasia bank, yaitu kelaziman operasional bank yang menyangkut pada penghimpunan dana masyarakat seperti melalui giro, tabungan, deposito, dan lain sebagainya. Adapun setelah melakukan penghimpunan dana tersebut bank perlu untuk menyebarkan dana tersebut kepada masyarakat yaitu melalui pemberian kredit. Upaya lainnya, yaitu pencatatan yang memadai dalam operasi bank atau transaksi yang dilakukan bank merupakan suatu keharusan. Memadai atau tidaknya catatan itu diukur dengan kesanggupannya memenuhi berbagai permintaan terhadap informasi mengenai setiap kegiatan bank. Bila pencatatan dan administrasi perbankan kurang baik maka kelancaran kegiatan perbankan akan mendapat gangguan.

\section{Daftar Pustaka}

\section{Buku}

Abdulkadir Muhammad, Hukum Perdata Indonesia, PT. Citra Aditya Bakti, Bandung, 2000.

Adrian Sutedi, Hukum Perbankan (Suatu Tinjauan Pencucian Uang, Merger, Likuidasi, dan Kepailitan), Sinar Grafika, Jakarta, 2010.

Andri Soemitra, Bank dan Lembaga Keuangan Syariah, Prenada Media, Jakarta, 2010.

Kasmir, Bank dan Lembaga Keuangan Lainnya, PT. Raja Grafindo Pustaka, Jakarta, 2002.

Muhammad Djumhana, Rahasia Bank (Ketentuan dan Penerapannya di Indonesia), PT. Citra Aditya Bakti, Bandung, 1996.

Bandung, 2003.

, Hukum Perbankan di Indonesia, PT. Citra Aditya Bakti,

Munir Fuadi, Hukum Perbankan Modern, PT. Citra Aditya Bakti, Bandung, 1999.

Juli Irmayanto, Bank dan Lembaga Keuangan Lainnya, Media Ekonomi Publishing FE Universitas Trisakti, Jakarta, 1998. 
Rachmadi Usman, Aspek-Aspek Hukum Perbankan di Indonesia, Gramedia Pustaka Utama, Jakarta, 2001.

Zulfi Diane Zaini, Independensi Bank Indonesia dan Penyelesaian Bank Bermasalah, Keni Media, Bandung, 2012.

\section{Perundang-Undangan}

Undang-Undang Nomor 13 Tahun 1968 tentang Bank Sentral.

Undang-Undang Nomor 7 Tahun 1992 tentang Perbankan yang kemudian sebagian pasal-pasalnya telah diubah dan ditambah dengan Undang-Undang Nomor 10 Tahun 1998.

Undang-Undang Nomor 10 Tahun 1998 tentang Perubahan Undang-Undang Nomor 7 Tahun 1992 tentang Perbankan.

Undang-Undang Nomor 23 Tahun 1999 tentang Bank Indonesia yang kemudian sebagian pasal-pasalnya telah diubah dan ditambah dengan Undang-Undang Nomor 3 Tahun 2004 dan terakhir diubah dengan Undang-Undang Nomor 6 Tahun 2009.

Undang-Undang Nomor 24 Tahun 2004 dan diubah dengan Undang-Undang Nomor 7 Tahun 2009 tentang Lembaga Penjamin Simpanan.

Undang-Undang Nomor 21 Tahun 2011 tentang Otoritas Jasa Keuangan.

Peraturan Pemerintah Pengganti Undang-Undang Nomor 23 Tahun 1960 tentang Rahasia Bank. 